\title{
HAS THE CONDUCT-BASED APPROACH TO COMPETITION LAW in South Africa Led to Consistent interpretations of HARM TO COMPETITION?
}

\author{
Ryan Hawthorne ${ }^{1}$ \\ Competition Commission South Africa
}

\begin{abstract}
The Competition Act and certain recent decisions by the competition authorities are examined here to assess the extent to which South Africa's conduct-based approach to competition law has led to consistent outcomes in the assessment of effects on competition. This has not been the case in the assessment of anti-competitive effects among customers or resellers when a supplier accused of an anti-competitive action does not compete with its customers. An anti-competitive effect among customers or resellers is treated as anti-competitive when it arises from some form of conduct, such as price discrimination. However, it is not seen as anti-competitive when it arises from a refusal to supply, for example. Possible reasons for South Africa's conduct-based approach and this inconsistent outcome in the assessment of competition among customers and resellers, including the economic foundations of the relevant approaches and their relationship with competition law in other jurisdictions, are assessed.
\end{abstract}

Abstract

JEL K21, L41

\section{1 \\ Introduction}

Recent decisions on price discrimination, vertically restrictive practices, and the abuse of dominance in South Africa have used inconsistent approaches to the assessment of harm to competition. In this article, the writer reflects on the Competition Act, no. 89 of 1998 (hereafter referred to as the Act), and on decisions made in South Africa by the Competition Tribunal (the Tribunal) and the Competition Appeal Court (the CAC), bearing in mind the different conduct-based approaches to the assessment of harm to competition.

The central thesis of this article is that the same effect arising from different forms of conduct is not treated equally under different sections of the Competition Act. This is particularly in respect of a lessening of competition among customers of a supplier firm accused of an anticompetitive action, where the latter does not compete with its customers, as it is treated as less anti-competitive in some sections of the act than in others. Especially important is the distinction between requirements to prove a "refusal to supply a scarce good" contravention, and requirements to prove that vertical agreements and price discrimination lessen competition. When a dominant firm refuses to supply a customer, and when the dominant firm does not compete with its customers, a reduction in competition among customers is not a sufficient theory of economic harm to show a contravention of the refusal to supply provision of the Act, while reduction in competition among customers or resellers may be sufficient to show a contravention under vertical agreements and price discrimination.

Thus harm to competition among customers or resellers of the upstream supplier's product, known as intra-brand competition, where resale of the good in question is involved, or known as competition in the "second line" in the price discrimination literature, is not enough to show an anti-competitive effect for a refusal to 
supply case. This should be contrasted with the authorities' decisions on vertical agreements in pharmaceutical distribution as well as with price discrimination in Nationwide Poles vs Sasol. In the latter two cases, a substantial lessening of competition downstream among customers was considered to be an anti-competitive effect, even though the dominant firm upstream was not in competition with the downstream customer. The per se prohibition on minimum resale price maintenance stems from concerns about anti-competitive effects downstream among resellers, and does not rely on the upstream firm extending its market power as a theory of harm; the prohibition in the Competition Act of resale price maintenance does not even require proof of dominance upstream, let alone the creation or maintenance of monopoly there, suggesting that harm to intra-brand competition or competition among resellers is a particularly egregious offence.

These differences within the Act and in the case law are intended to reflect the probability that certain kinds of agreements or actions are more likely to be harmful to competition than are others, and are intended to provide clarity to firms on what they can and cannot do. The provisions of the Act emanate from experience with these practices in other jurisdictions. A key question that arises is whether the conduct-based approach adopted is based on economic theories of pro-competitive and anti-competitive effects arising from different forms of conduct. A further key issue is how international competition law has impacted on our competition legislation and jurisprudence in respect of the conduct discussed here, and whether international precedent has been employed consistently.

First, an analysis of relevant cases is presented. The economics literature is then assessed to see whether any clear conclusions emanating from it have guided the establishment of the conductbased approach. The Act and the authorities' use of international precedent are then examined to see whether an explanation of the conduct-based approach could be found there. Conclusions are provided thereafter.

\section{2}

\section{Inconsistent results in applying the conduct-based approach}

\subsection{Refusal to supply}

Refusal to supply is one of the "named" abuses found in section $8(d)$ of the Act, which says that:

it is prohibited for a dominant firm to engage in any of the following exclusionary acts, unless the firm concerned can show technological, efficiency or other procompetitive gains which outweigh the anticompetitive effect of its act - (i) requiring or inducing a supplier or customer to not deal with a competitor; (ii) refusing to supply scarce goods to a competitor when supplying those goods is economically feasible; (iii) selling goods or services on condition that the buyer purchases separate goods or services unrelated to the object of a contract, or forcing a buyer to accept a condition unrelated to the object of a contract; (iv) selling goods or services below their marginal or average variable cost; or (v) buying-up a scarce supply of intermediate goods or resources required by a competitor. [Own emphasis]

The prohibitions of refusal to supply, and inducement, which are both relevant to the rest of the paper, are per se abuses, in the sense that there is no need to prove that the conduct in question is exclusionary ${ }^{2}$. They require that the firm alleged to have contravened the Act be dominant and that the exclusionary act has an anti-competitive effect. An efficiency defence is allowed, but the onus is on the respondent to prove this. A fine for a first offence is allowed. ${ }^{3}$

In a series of decisions on refusal to supply, including York Timbers vs Safcol ${ }^{4}$ and The Bulb Man vs Hadeco ${ }^{5}$, the Competition Tribunal has held that, in order to show a contravention, the firm that is abusing its dominance must be able to preserve, increase, create or threaten to create market power through the abuse. This, they say, is a consequence of the presence of 
the word "competitor" in section 8(d)(ii) (see above). The Competition Appeal Court upheld the Competition Tribunal's decision in York Timbers ${ }^{6}$.

In both York Timbers and The Bulb Man, the Tribunal held that, as both complaining firms operated downstream, and the respondents operated predominantly in the upstream markets, the dominant firms were not expanding their market power in refusing to supply and their behaviour was therefore not a contravention of the Act. The abuse must be linked to the incentives of the dominant firm in the authorities' estimation; the only intention or incentive that the authorities admit in order for refusal to supply to be an anti-trust violation is the intention to monopolise a market.

The Tribunal relies on Areeda and Hovenkamp (2005: 167) for its interpretation of exclusionary conduct in respect of refusal to supply?:

An 'arbitrary' refusal to deal by a monopolist cannot be unlawful unless it extends, preserves, creates, or threatens to create significant market power in some market, which could be either the primary market in which the monopoly firm sells or a vertically related or even collateral market. Refusals that do not accomplish at least one of these results do not violate Section 2 (of the Sherman Act), no matter how much they might harm the person or class of persons declined service. Nor are such refusals an 'abuse' of monopoly power in the sense of using power in one market as 'leverage' to increase one's advantage in another market.

In analysing refusal to supply cases in this way, the competition authorities effectively do not take into account anti-competitive effects downstream among customers of the dominant firm in question, when the dominant firm does not compete with its customers. This is premised on the fact that no dominant firm has the incentive to restrict competition downstream if it is not present there to benefit from it. The Tribunal in York Timbers ${ }^{8}$ again quoted Areeda and Hovenkamp (1996: 193):

The danger of 'abuse' through arbitrary refusals to deal seems quite low. Substantial monopolies, run by directors responsible to stockholders, will generally behave rationally and make all profitable sales.

This is in stark contrast to the analysis of price discrimination that the authorities undertook (discussed below), when the focus of the complaint was on anti-competitive effects among customers. This was despite the fact that the dominant supplier was not competing with customers. Furthermore, the Tribunal did not dismiss harm to competition among customers as a potential theory of harm to competition during discussions in the authorities' decisions in respect of vertical agreements. This analysis is also at odds with the Tribunal's decision in the Mittal case, in which the Tribunal's remedy was to force Mittal to relinquish control of resale of its products, or competition among its resellers and customers. This was done to bring the prices of steel down by essentially allowing steel customers to engage in arbitrage activities. ${ }^{9}$ This is precisely what Mittal prevented through "ancillary conduct", in restricting resale of its product downstream. The authorities' approach to refusal to supply also ignores the low burden of evidence required to prove a minimum resale price maintenance contravention, which concerns itself primarily with competition among the resellers of a firm's products. Each of these applications of harm to competition downstream, in which the upstream supplier does not compete downstream, are discussed next, beginning with vertical agreements.

\subsection{Vertical agreements}

The vertical agreements referred to here were alleged to be vertically restrictive practices prohibited under section 5(1) of the Act. This section of the Act requires that an anticompetitive effect of an action must be shown ${ }^{10}$ although evidence of dominance in any market is not required. An efficiency defence is allowed and a fine for a first offence is not permitted. The Tribunal has not dismissed harm to competition among customers as a theory of harm in at least one case in which vertical agreements were involved. The upstream supplier was not present downstream, and thus had no "monopolisation" incentive to engage in the conduct. 
In Natal Wholesale Chemists vs Astra, Merck and Pharmaceutical Healthcare Distributors, the Tribunal contemplated effects on competition between customers, and ruled them out on the facts of the case, not in principle ${ }^{11}$. The complaint was brought under section 5(1) (vertically restrictive practices) and section 9 (price discrimination) of the Act. In that case, the Tribunal devoted several paragraphs to assessing the competition impact at the level of the resellers, or harm to "intra-brand" competition, even though the upstream supplier in question, and the only plausible monopolist in this case, was not competing downstream with its resellers. For example, the Tribunal said that ${ }^{12}$ :

[t]he claimant asserts that intra-brand competition has been eliminated by the exclusive distribution arrangement. This is, indeed, usually true per definition - where previously the same brand was available from a number of sellers, exclusivity in distribution implies that there will now be only a single source for the branded product. Standard anti-trust treatment of the elimination, through exclusive distribution arrangements, of intra-brand competition is to balance this diminution of intra-brand competition against the pro-competitive impact of the same arrangement on interbrand competition.

Thus the elimination of competition among resellers was an important consideration in the Tribunal's assessment. This was not ruled out on the basis that there was no intention on the part of the supplier to monopolise the market; the supplier in this case did not compete downstream with its resellers ${ }^{13}$. One might argue that it was the reseller, Pharmaceutical Health Distributors (PHD), who sought in this instance to exclude its rivals through the agreement; in these circumstances, the agreement would have been born of intent to monopolise a market. Nonetheless, this could not have been the Tribunal's conception of the case; it was manifestly the case that the pharmaceutical manufacturers upstream rather than the downstream distributor, PHD, were in possession of market power. Ultimately, the Tribunal ruled that the complainants did not present evidence of harm to competition, that their theory of harm to intra-brand competition was not supported by any evidence. The complainant did not persist with the price discrimination part of the complaint during the proceedings, so the Tribunal dismissed it.

The Tribunal has thus allowed that anticompetitive effects among customers, where the upstream firm in question does not compete with its customers, could be a substantial lessening of competition under some sections of the Act but not under others.

\subsection{Minimum resale price maintenance}

More evidence of the Act and implementing authorities' inconsistent approach to assessing harm to competition among resellers is in the per se prohibition of minimum resale price maintenance (minimum RPM). This is when an upstream supplier chooses to enforce a minimum resale price on downstream suppliers, thus expressly limiting competition between the latter firms. Minimum resale price maintenance is prohibited under section 5(2) of the Act, and is prohibited per se, which means in this case that once the agreement or practice has been proven to exist, there is no additional burden of proof placed on a complainant to prove that the firm perpetrating the abuse is dominant, nor that there is an anti-competitive effect or an anti-competitive effect that outweighs any pro-competitive effect. A fine for a first offence is permitted.

The per se prohibition of minimum RPM seems to stem from the lessening of competition among resellers. This prohibition does not even require showing that the upstream firm is dominant; a supplier that is a very small competitor on the margins of a product or geographic antitrust market will be guilty of an offence if it requires its distributors or retailers not to sell below a minimum price, despite the well-known efficiencies that can emanate from minimum resale price maintenance (discussed below).

Certain anti-competitive effects can arise upstream among the manufacturers of a product from resale price maintenance, so there are possible reasons for its per se prohibition outside of its impact on competition among resellers ${ }^{14}$. 
The main one is facilitating collusion between manufacturers or "upstream" producers, in that wholesale prices are made more transparent to competitors the less retailers compete, and prices are varied for the supplier's benefit (Church \& Ware, 2000: 694). In the same vein, if the upstream supplier has a commitment problem in respect of collusion, delegating pricing to a downstream firm, and setting a minimum price, can go some way to alleviating this (Motta, 2004: 338). Note that this conception of harm to competition does not envisage intent to monopolise another market, the harm required under refusal to supply.

Since the rules of the Competition Act are intended to reflect the different levels of harm to competition arising from each form of conduct, it would appear that resale price maintenance, which does not require much in order to show a contravention, and which restricts reseller competition and does not rely on a conception of harm that relates to monopolisation of the market in which the upstream supplier competes, is among one of the most egregious offences to be committed by a firm. In Seven Eleven, the Tribunal noted of resale price maintenance that ${ }^{15}$ :

We are dealing here with one of a small class of restrictive practices deemed so pernicious an antitrust violation that it is prohibited per se.

It is difficult to see how restrictions of competition among resellers, a lessening of competition that does not require an attempt by the dominant firm to monopolise the market, could be so harshly opposed in one part of the Act and so permissively accepted in others.

\subsection{Price discrimination}

Section 9(1) of the Act contains the prohibition of price discrimination by a dominant firm. The contents of this section are similar to those of the abuses prohibited under section 8(d)(ii) (the prohibition of "refusal to supply"), given that dominance and anti-competitive effects must be present in order for a contravention to be found. One distinction between $9(1)$ and $8(d)$ is that $9(1)$ states that there must be a "substantial lessening or prevention of competition" under price discrimination (the same wording used for the assessment of mergers), while section 8(d) says there must be an "anti-competitive effect". However, in practice there does not appear to be any difference in interpretation ${ }^{16}$. The prohibition of price discrimination bears a similarity to section 5(1) (which contains the prohibition on vertically restrictive practices other than minimum RPM), which requires a "substantial lessening or prevention of competition", although dominance is not required to show a contravention of section $5(1)$.

However, the defences for price discrimination are more specific than those for the other sections discussed here. While sections $8(\mathrm{~d})$ and 5(1) permit of "technological, efficiency or other pro-competitive gains" as defences, price discrimination that results in a substantial lessening of competition is permitted only under specific circumstances, such as where the costs of manufacture, sale or distribution of the good are different, where the firm has charged a different price to meet the price of a competitor, or where the discrimination is a response to changing circumstances like deterioration of perishable goods, obsolescence of a product, a sale pursuant to a liquidation, or discontinuance of the business in the goods in question. No fine is permitted for a first offence in price discrimination.

There are therefore similarities and differences between price discrimination on the one hand, and vertically restrictive practices and exclusionary abuses of dominance, such as refusal to supply and inducement, on the other hand, which emanate from the language and structure of the Act. The key similarity running across sections 5(1), 8(d) and 9(1) is the requirement that, in order for a contravention to be found, an anti-competitive effect must have arisen. Therefore, the Act has in mind some concept of economic harm under each section. However, at the same time, the same economic harm is not treated equivalently under the different parts of the Act that focus on conduct.

The only instance in which the Competition Tribunal found in favour of a complainant in a 
price discrimination case was Nationwide Poles vs $\mathrm{Sasol}^{17}$. In that case, both the Competition Tribunal and the Competition Appeal Court in their analysis of effects on competition evaluated a substantial amount of evidence on anticompetitive effects among customers of Sasol, though in that case Sasol did not compete with its customers. This is in contrast to their analysis of anti-competitive effect among competitors only when assessing complaints brought under section 8(d)(ii) of the Act (the prohibition of refusal to supply). The Tribunal accepts that the standard for anti-competitive effect under price discrimination may be lower than that for a contravention of section $8(\mathrm{~d})^{18}$.

All four pages of the Tribunal's decision devoted to evaluating a substantial lessening of competition dealt with effects among customers, and much of the Competition Appeal Court's ruling analysed anti-competitive effects in this way too. Even though the dominant firm in that case had no direct profit incentive to engage in the price discrimination, other reasons may have persuaded it to do so. One reason is buyer power exerted by the larger pole producers who sought to exclude their rivals. Buyer power, combined with the dominant firm seeking out "the quiet life", seems to account for Sasol's behaviour in the Tribunal's reckoning.

As the Tribunal put it, in respect of the "quiet life":

Monopolists - or, in the parlance of our Act, dominant firms - extract their rents in one of two forms: supra-competitive profits or, as the eminent British economist, Sir John Hicks, famously termed it, the 'quiet life'. In this case we have a very large producer of petroleum and chemical products seeking to dispose of a product - creosote - that is marginal relative to the firm's total output. It has no particular interest in expanding output of this product. In fact it appears that technical considerations limit this option. As we have shown, the commercial considerations of the greater Sasol subordinate decisions regarding the pricing and output of creosote to far weightier issues, namely the fuel equivalent price of the feedstock and the need to optimise the composition of the bouquet of products derived from the feedstock. Sasol's primary interest is in disposing of its variable output of creosote, the variances being driven by exogenous factors.

In Nationwide Poles, the Tribunal more or less adopted as the correct approach for the interpretation of section 9 of the SA Competition Act the approach in the USA's Robinson-Patman Act, which contains the USA's prohibition on price discrimination. The Robinson-Patman Act emanates from a theory of buyer power. The law was put into place because of the concerns of small green grocers that were going out of business as a result of the large buying power of the supermarket chains ${ }^{19}$. In this theory, Sasol's larger customers, it could be argued, induced Sasol not to deal with smaller customers. This conduct could fall foul of section 8(d)(i) of the Competition Act, which contains the prohibition of inducement, should any of Sasol's buyers have been dominant.

There is some inconsistency in both the Act and the authorities' approach to inducement and price discrimination on this score. In the Nationwide Poles case, it was unlikely that the case run under $8(\mathrm{~d})(\mathrm{i})$ would be successful, even though it was, in fact, successfully run, at least at the Tribunal stage, under section 9(1). This is because no single pole supplier appeared to be dominant, and, while "joint dominance" was a possibility available to the complainant (although this has not been ruled on by the authorities and is not directly referred to in the Act), this would have required a substantial amount of evidence. According to the CAC:

...figures placed before the Tribunal as provided by the South African Wood Preservative Association indicated the existence of a fairly robust and diverse market. From this information it appears that there were more than 30 timber treaters and agents in South Africa, of which ten offered both creosote and copper chrome arsenate ('CCA'), twelve of which offered CCA only and seven only creosote. The report also indicated that ten firms out of the approximately 34 fell into the smallest category of purchasers of creosote but had continued to do business throughout the relevant period. 
In a case like this, with 30 competitors (according to the respondent's expert, there were even more than 30), there is a substantial likelihood that no individual pole treater would be found dominant, and a case of joint dominance would in all likelihood be difficult to make out. This being the case, no dominant firm could be "inducing" its suppliers not to deal with competitors in contravention of the Act, even though a lessening of competition arose, at least in the Tribunal's view. In this case the dominant firm in question, Sasol, did not intend to monopolise a market; notwithstanding, there was no less of an anti-competitive effect arising from Sasol's conduct, at least in the Tribunal's view.

There are other explanations at least for the Tribunal's views on Sasol vs Nationwide Poles other than harm to competition, including its emphasis on the protection of small business in the "public interest" 20 . The Tribunal said that Sasol's conduct was prohibited because it was manifestly unfair and was contrary to the government's policy to develop Small, Medium and Micro-Enterprises (SMMEs). The Tribunal said that price discrimination was there to protect small customers in particular, because "it is unlikely that a discriminator will discriminate against a large customer unless that customer is also a competitor ${ }^{21}$." Price discrimination thus has a special place in the Competition Act, which means that harm to small business must be evaluated. However, it is not clear why small business ought to have greater protection when the supplier in question engages in price discrimination rather than another form of conduct which has an equally detrimental impact on small business, such as inducement or refusal to supply.

With respect to price discrimination, the Competition Appeal Court did not explicitly say that an anti-competitive effect among customers would be sufficient to show harm to competition ${ }^{22}$. On the other hand, they did not rule this out, and they certainly devoted a substantial number of pages to assessing competitive effects among customers. Both institutions agreed that the construction of the Act, which separates price discrimination from Section 8 of the Act (which, in turn, deals with abuses of dominance), means that the section should be interpreted differently. The CAC differed from the Tribunal as to the burden of evidence required for showing price discrimination to be anti-competitive in requiring evidence of exit or inability to compete among the class of firms discriminated against. The Tribunal simply required that the sections of the Act had been shown (in other words that, inter alia, there is price discrimination, that the transactions are equivalent, and that the conduct affected competition among firms) ${ }^{23}$.

Effectively, Sasol's pricing decisions may have been precluding firms from competing in markets unrelated to those in which Sasol competes, although ultimately the CAC found that there was insufficient evidence to prove this. However, it is not clear why anti-competitive harm downstream is any less harmful to competition, regardless of whether it is on account of price discrimination, inducement or refusal to supply.

\subsection{Excessive pricing and the restriction of competition among resellers and customers}

An important example of harm to competition among resellers by exclusionary practices, such as refusal to supply and vertical restraints, both in turn ultimately resulting in higher prices, is Mittal's conduct in the steel industry. In Harmony vs Mittal $^{24}$, Mittal's exclusive export arrangement with Macsteel amounted to a refusal to supply other firms wishing to both export products and sell the same steel in the local market, as these resellers would have required a substantially lower price than the local price (set at importparity) to sell on the export market. This would have eroded Mittal's ability to charge excessive prices locally, given the fungible nature of steel, which allows resellers to resell the good locally at the cheaper export price ${ }^{25}$. Similarly, Mittal supplied downstream customers who either competed with firms using products other than steel as an input or faced some other competitive constraint at lower prices than import-parity prices but required these customers not to resell their cheaper steel in competition with Mittal's own resellers. 
Mittal used the exclusive deal with Macsteel in respect of exports, as well as a complex system of regulation of customers that received discounts, which amounted to vertically restrictive practices preventing their reselling steel, to ensure that Mittal customers could not compete with Mittal's resellers. Through this system, Mittal was able to price discriminate among its customers and preserve excessive prices to many of them. Without the vertically restrictive practices, Mittal would not have been able to charge excessive prices and, indeed, the Tribunal has instructed Mittal to unwind those practices as a means of remedying Mittal's behaviour. While a reduction in competition between resellers of Mittal's steel was not the anti-competitive effect alleged, it was the means by which Mittal has been able to maintain excessive prices.
Mittal's conduct therefore resulted in an anticompetitive outcome in excessive prices, even though Mittal was not present downstream and had no direct incentive to restrict competition in the narrow sense of driving out rivals and monopolising the industry downstream.

\subsection{Summary: the rules with respect to anti-competitive among customers}

In summary, the Act and the authorities' approach to assessing anti-competitive effects among customers or resellers where the firm alleged to have contravened the Act does not compete with its customers or resellers reveals that it is the conduct in question that matters rather than the effects on markets. A summary of the rules and the requirements under the Act discussed in this paper are shown in the table below.

\section{Summary table}

Evidence needed to prove a contravention of the Competition Act and penalties available

\begin{tabular}{|c|c|c|c|c|c|c|}
\hline Contravention & $\begin{array}{l}\text { Conduct in } \\
\text { question } \\
\text { must be } \\
\text { proven } \\
\text { to have } \\
\text { occurred }\end{array}$ & $\begin{array}{l}\text { Complainant } \\
\text { must prove } \\
\text { dominance }\end{array}$ & $\begin{array}{l}\text { Complainant } \\
\text { must prove } \\
\text { anti- } \\
\text { competitive } \\
\text { effect }\end{array}$ & $\begin{array}{l}\text { Pro- } \\
\text { competitive } \\
\text { effects } \\
\text { defence } \\
\text { available to } \\
\text { respondent }\end{array}$ & $\begin{array}{l}\text { Anti- } \\
\text { competitive } \\
\text { effects among } \\
\text { resellers / } \\
\text { customers } \\
\text { where } \\
\text { supplier } \\
\text { does not } \\
\text { compete with } \\
\text { customers } \\
\text { is harm to } \\
\text { competition }\end{array}$ & $\begin{array}{l}\text { Tribunal } \\
\text { may } \\
\text { impose } \\
\text { a fine for } \\
\text { the first } \\
\text { offence }\end{array}$ \\
\hline $\begin{array}{l}\text { Minimum } \\
\text { resale price } \\
\text { maintenance } \\
-5(2)\end{array}$ & $x$ & & & & $x$ & $x$ \\
\hline $\begin{array}{l}\text { Other vertically } \\
\text { restrictive } \\
\text { practices - 5(1) }\end{array}$ & $x$ & & $x$ & $x$ & $x$ & \\
\hline $\begin{array}{l}\text { Exclusionary } \\
\text { Acts in } 8(d) \\
\text { - e.g. refusal to } \\
\text { supply, } \\
8 \text { (d)(ii) }\end{array}$ & $x$ & $x$ & $x$ & $x$ & & $x$ \\
\hline $\begin{array}{l}\text { Price discrimi- } \\
\text { nation - } 9(1)\end{array}$ & $x$ & $x$ & $x$ & $\begin{array}{l}\text { Certain } \\
\text { defences } \\
\text { are allowed }\end{array}$ & $x$ & \\
\hline
\end{tabular}


A key question arising is whether there are any economic theories that support the conductbased approach adopted in the Act, which would mitigate any need to interpret harm to competition among customers or resellers in a consistent way. Are there any forms of conduct that are clearly more anti-competitive than pro-competitive? This question is discussed in the next section.

\section{3}

\section{Economic theories about competition among resellers that might explain the conduct-based approach}

The Act and the competition authorities have adopted a conduct-based approach to assessing conduct under the Competition Act, which has led to inconsistent outcomes in taking into account effects on competition among customers and resellers. The extent to which the rules discussed in this paper emanate from economic theory is assessed here. The first question dealt with is: Are there good theoretical reasons for ignoring competition among resellers as a theory of harm to competition?

One explanation for the Act and the authorities' sceptical approach to the matter of harm to reseller competition or competition among customers in relation to exclusionary practices is the influence of the Chicago School of thought, which essentially says that there is one monopoly profit that a monopolist can make, and firms with market power can earn that profit without engaging in any other vertically restrictive practice (Motta, 2004:363) ${ }^{26}$. There is therefore no incentive for a monopolist to reduce competition in a vertically related market, whether the monopolist is present there or not. The only explanation for any such restriction is that it must be efficient, which is discussed in more detail below.

However, this approach is entirely at odds with the Act and the authorities' approach to assessing anti-competitive effects arising from resale price maintenance, which prohibits, conduct that the Chicago School would not see as anti-competitive. Also, the one monopoly profit theory holds only under very specific conditions, namely that there is a monopoly input supplier, the monopolist operates in an unregulated industry, competition downstream is perfect, and inputs are used in fixed proportions to produce the output (Salop \& Riordan, 1995: 517). Without these conditions, the one monopoly profit theory does not hold and the Chicago School critique is invalid.

In any event, there are reasons for a monopolist to restrict competition downstream, exemplified clearly in the Mittal case discussed above. Furthermore, as in Nationwide Poles, large customers, while not individually dominant, could prevail upon large upstream suppliers to limit competition among customers; upstream monopolists might go along with this strategy for no other reason than to pursue the "quiet life". Finally, competition among resellers or customers is sometimes worth preserving because of the "credibility problem" faced by the monopolist.

Dominant firms may want to reduce competition downstream because of the credibility problem they face when selling to multiple resellers. Imagine an industry with an upstream monopolist and several downstream resellers, with whom the monopolist engages sequentially. Once the monopolist upstream has set a price and quantity to its first reseller, on the basis that the price at which the retailer will be able to resell the quantity of goods is on a level at which some of the monopoly profit will be shared, the upstream monopolist has an incentive to discount to the next reseller in order to sell the next quantity of goods. The first reseller will lose some of the profits it has negotiated with the upstream monopolist as they will be forced to charge a lower price, while the monopolist keeps the profits from both resellers (see Motta, 2004: 338-343). Consequently, the first reseller will not accept the high price in the first place, and the monopolist will not be able to extract its monopoly profit. By reducing competition downstream (in the sense of reducing the number of competitors) by refusing to supply or otherwise, the monopolist's credibility in maintaining high prices is more easily maintained, and the "one monopoly profit" is restored. 
Furthermore, to the extent that an upstream firm has a collusive arrangement with its competitors, whether explicit or tacit, the more stable it can make downstream prices the more likely that its prices will be transparent to its competitors and the collusive arrangement will be maintained (Motta 2004: 358-360); this is related to the discussion on minimum resale price maintenance above. There are therefore good reasons for a dominant firm upstream to limit competition downstream even where the dominant supplier does not compete downstream, and therefore does not intend to monopolise the downstream market. This could be achieved by different forms of conduct, including refusal to supply or vertical restraints.

There do appear, therefore, to be good reasons for firms to limit competition among customers that are not limited to one particular form of conduct. There are thus no strong reasons for one form of conduct to be presumptively more anti-competitive than another. The next question that arises is: are practices such as resale price maintenance and price discrimination less likely to result in efficiencies than practices such as refusal to supply or inducement, even though they have an equivalently negative effect on competition?

Vertically restrictive practices, such as minimum resale price maintenance, can result in a number of efficiencies. At the extreme end of the continuum of views on efficiencies arising from vertically restrictive practices is the Chicago School. Proponents of this school of thought say that there ought to be a presumption in favour of vertically restrictive practices. Efficiencies arising from vertically restrictive practices relate to the minimisation of transaction costs. These include the costs of re-negotiating contracts regularly, and search costs involved in finding alternative suppliers. A further efficiency is the avoidance of "hold-up", which arises from "specific investments"; these occur when, for example, a retailer invests in a supplier's branding in its shops; hold up occurs when partners bargain after specific investments have been made (the retailer has installed the supplier's branding) and can lead to extraction of rent by one of the trading partners. Hold-up reduces incentives for investment in the first place. Vertically restrictive practices reduce both firms' ability to do this ${ }^{27}$. Transaction cost economics has, over the last 35 years, had a substantial impact on the interpretation of vertical restraints by the US courts, which used to interpret such restraints far less favourably, although the US Supreme Court has not had to rule on vertical restraints over the entire period (Gellhorn et al., 2004: 399).

Exclusive dealing arrangements through longterm contracts can effectively reduce the risk of "hold up" by one party, which would otherwise reduce or eliminate the incentive to invest in the first place. The car industry provides a useful illustration of this point: in 1978, General Motors (GM) in the US agreed to buy closedmetal body parts exclusively from one supplier under a long-term contract, which reduced GM's ability to renegotiate the terms of the contract once the closed body parts manufacturer had made specific investments in auto-body dies, equipment that can be designed to produce a specific product for a specific customer (Church \& Ware, 2000: 78,79) ${ }^{28}$.

Exclusive dealing arrangements and other vertically restrictive practices like minimum resale price maintenance can also lead to the elimination of free-riding by downstream resellers. Without vertical restraints, competition among resellers might result in the underprovision of certain services or warranties, as no individual reseller has the incentive to invest in providing after-sales services or before-sales services (such as advice on a product) if customers can consume those services (receive the advice) but buy the product at another reseller's outlet (Motta, 2004: 315) ${ }^{29}$. For example, Toys R Us entered into exclusive agreements with most of the toy manufacturers in the US, in return advertising these toy manufacturers' products. Toys R Us argued that, if it had not had this arrangement, it would not have advertised the manufacturers' products, as retailers that did not incur the advertising cost could sell the same product at a lower price (Church \& Ware, 2000: 683; Kwoka \& White, 2004: 373) $)^{30}$.

Like vertically restrictive practices, price discrimination too has efficiency enhancing effects. Price discrimination here refers to the 
economic meaning of the term, i.e. differences in mark-ups over costs for different sales of the same product ${ }^{31}$. Price discrimination may result in expansions of output to customers that would not otherwise be served, and might allow firms to be in business that would not otherwise have been able to exist profitably (Motta, 2004: 493). This is particularly the case in markets where there are substantial fixed costs. Where there are high fixed costs, with resulting economies of scale, price discrimination allows higher mark-ups over marginal costs to be allocated to groups of consumers that will least reduce their consumption in response to higher prices (consumers who have a low price elasticity of demand); thus output of the good or service in question is maximised (Church \& Ware, 2000: 788) ${ }^{32}$.

Price discrimination is also a means of undermining collusion in oligopolistic markets. By charging a price to one customer that is below the price charged to another, a firm reduces the transparency of its pricing to its competitors, which is an important pre-requisite for monitoring collusion, tacit or otherwise (Motta, 2004: 500).

There is therefore no clear reason arising from economic theory to be particularly interventionist in respect of conduct like price discrimination or minimum resale price maintenance on the basis that it has fewer procompetitive benefits than, say, refusal to supply. Nonetheless, the burdens of proof and the tests employed in resale price maintenance and price discrimination cases are much more likely to lead to complaints being successfully brought under those sections than complaints brought under the exclusionary practices sections of the Act, even though the anti-competitive effects are similar.

In summary, there are no clear rules emanating from the economics literature for what sorts of conduct are more or less likely to result in anti-competitive effects that outweigh procompetitive effects for the forms of conduct examined in this paper. There is therefore no clear set of economic theories underlying the conduct-based rules found in the Act and the authorities' decisions.

Rather, the conduct-based approach established in the Act and by the authorities emanates from experience in other jurisdictions. Section 1(3) of the Competition Act says that "any person interpreting or applying this Act may consider appropriate foreign and international law". A question arising from this is: Which foreign rules have been used, and what does this mean for the interpretation of harm to competition? This is discussed in the next section.

\section{4}

\section{The adoption of US vs EU antitrust philosophies}

The Act and the authorities' approach to treating differently anti-competitive effects among customers where the firm in question does not compete with its customers in abuses such as refusal to supply and price discrimination is consistent with the US approach to competition law. The Robinson-Patman Act in the US, as discussed above, governs the relevant prohibition of price discrimination, which admits of anti-competitive effects among customers where the firm perpetrating the abuse does not compete with its customers. At the same time, in the US, for refusal to supply cases, "monopolisation" of the relevant market is required. Anti-competitive effects among customers, where the firm refusing to supply does not compete with its customers, are not examined (also discussed above).

At the same time, the CAC in Nationwide Poles was willing to adopt in principle an approach to harm to competition in respect of abuse cases in accordance with EU competition law, which captures a greater range of conduct than that captured under US law. In describing what a lessening of competition means, the CAC in Nationwide Poles quoted Professor Eleanor Fox, who refers to Article 82 of the EC Treaty, which contains the EU prohibition of both price discrimination as well as exclusionary abuses such as refusal to supply, thus ${ }^{33}$ :

Article 82 still prohibits abuse of dominance, not just its creation and maintenance. I find no reason to believe that EC Law will abandon its concern that dominant firms may use their power to appropriate 
advantages for themselves at the expense of competitors, nor to abandon its vision of harm to competition that regards open market, access on the merits, and safeguarding of the market mechanism as mainstays of healthy competition.

Notably, under EU law, the "intent" of the firm accused of a contravention is not at the heart of the enquiry. Professor John Vickers (2004: 17) notes:

A related question is whether and when conduct can harm competition unlawfully but without any anti-competitive intent (let alone sacrifice). Recall that in European law abuse of dominance is an objective concept and can exist without anti-competitive intent - hence Richard Whish (2003, page 194) says that "intention is not a key component of the concept of abuse". The dominant firm has a special responsibility not to impair undistorted competition.

The Act and the authorities have therefore imported into South African competition law inconsistencies in US law in the assessment of competition among customers, where the firm perpetrating the abuse does not compete with its customers. Harm to competition among customers is not evidence of harm to competition for exclusionary abuses such as refusal to supply but it is a theory of harm where price discrimination is concerned. This is at odds with the authorities' willingness to accept an extended interpretation of abuse of dominance, at least in the CAC's acceptance of EU principles relating to Article 82 in Nationwide Poles, which examines wider theories of harm to competition.

\section{5}

\section{Conclusions}

In developing their approach to both refusal to supply and price discrimination, the South African competition authorities appear to import inconsistencies in US competition law, which is at odds with the SA authorities' acceptance of principles of EU law in relation to these forms of conduct. The EU has a somewhat wider interpretation of harm to competition.

The result of the conduct-based approach has been an inconsistent interpretation of what harm to competition means, and the risk that an outcome arising from one form of conduct would be a contravention, while the same outcome achieved by another form of conduct would not be. In particular, the Act and the authorities have ruled out examining anti-competitive effects among resellers or customers where the firm alleged to have contravened the Act does not compete with its customers or resellers, in section 8(d)(ii), while they accept examining these effects under sections 5(1) and 9(1).

The Act and the authorities' approach to section $8(\mathrm{~d})$ (ii) is also at odds with the approach in the Act in section 5(2), and the Tribunal's approach to section 8(a). The outright prohibition on minimum resale price maintenance (section 5(2)) expressly prohibits a form of conduct whose harm to competition is often felt among resellers and where monopolisation of a market by the firm engaging in the conduct is not relied upon as a theory of harm. Furthermore, in Harmony vs Mittal the Tribunal sought to undo the restriction of competition among customers and resellers in order to remedy Mittal's excessive pricing, prohibited under section 8(a).

It is important to note that there have been very few cases concerning prohibited practices and that the approach by the authorities to assessing conduct has generally been on a caseby-case basis. The authorities may move towards a more consistent approach to the assessment of harm to competition as the case law develops.

\section{Endnotes}

1 The views expressed here are his own and are not those of the Competition Commission South Africa. The author would like to acknowledge useful comments on drafts of this paper provided by Simon Roberts and two anonymous referees. The author is solely responsible for any remaining errors or omissions.

2 See Competition Tribunal decision in $S A A$ vs Commission, case number 18CRMar01, in paragraphs $96-105$.

3 Administrative penalties are dealt with under section 59 of the Act. 
4 See Competition Tribunal decision in York Timbers Limited and South African Forestry Company Limited, case number 15IRFeb01.

5 See Competition Tribunal decisions in York Timbers Limited and South African Forestry Company Limited, case number 15IRFeb01, from paragraph 88, and The Bulb Man (SA) (Pty) Ltd and Hadeco (Pty) Ltd., case number 81IRApr06, from paragraph 50.

6 See Competition Appeal Court decision in case number 09CACMay01.

7 Quoted in Competition Tribunal decision in case number 15IRFeb01, p. 20.

8 See Competition Tribunal decision in case number 15IRFeb01.

9 See Competition Tribunal decision in Harmony vs Mittal, case number 13CRFeb04; there are two relevant documents: the reasons for decision and the remedies.

10 See Competition Tribunal decision in Nationwide vs $S A A$ for the section 5(1) prohibition, case number 92IROct00, p. 16.

11 See Competition Tribunal decision in case number 98IRDec00.

12 See paragraph 61 of the Tribunal's decision, cited above.

13 Which was at least potentially the case in National Association of Pharmaceutical Wholesalers and others vs Glaxo Wellcome and others, since the pharmaceutical manufacturers in that case owned the downstream pharmaceutical distributor. See Competition Tribunal decision in case number 68IRJun00.

14 Another explanation for the per se prohibition of resale price maintenance not relating to the effect on competition among resellers (or competition at all) is that the prohibition in the USA (where it was also prohibited per se until very recently) is at least partially based on the common law relating to alienation of property rights (once ownership has passed, the selling firm should not interfere) rather than theories about anti-competitive effects (Gellhorn et al, 2004: 340), and the SA Competition Act has simply imported this historical quirk.

15 See Competition Tribunal decision in case number 18IRDec99.

16 See Competition Appeal Court decision in Nationwide Poles vs Sasol, case number 49CACApr05. See p. 38, for example, where the two terms seem to be used interchangeably.

17 See Competition Tribunal decision in Nationwide Poles vs Sasol, case number 72CRDec03.

18 See Competition Tribunal decision in The Bulb Man vs Hadeco, case number 81IRApr06, para. 43.
19 In fact, with one exception (druggists), the only industry proponents of the Robinson-Patman Act (and its various incarnations) during two sets of hearings were from the food industry, and all other industries opposed it (Edwards, 1959: p. 24).

20 See Competition Tribunal decision in Sasol vs Nationwide Poles, case number 72CRDec03, paragraph 142.

21 See Competition Tribunal decision in Sasol vs Nationwide Poles, case number 72CRDec03, paragraph 101.

22 See Competition Tribunal decision in The Bulb Man vs Hadeco, case number 81IRApr06, paragraph 67.

23 See Competition Tribunal decision in case number 72CRDec03 (Sasol and Nationwide Poles), from para. 75 , and the CAC decision in case number 49CACApr05, from p. 14.

24 See Competition Tribunal decision in case number 13CRFeb04r.

25 See Competition Tribunal decision in case number 13CRFeb04r. Note that there is no evidence that Mittal did refuse to supply other resellers wanting to export overseas; the exclusive nature of the deal with Macsteel certainly suggests that Mittal would have refused to supply other resellers wanting to export steel had they asked.

26 Note that the Tribunal does not necessarily subscribe to the one monopoly profit theory (OMPT), in that they would accept that, when a monopolist in an upstream market is present in the downstream market, an anti-competitive harm could arise, in that the monopolist would be excluding a competitor by, for example, refusing to supply them. In contrast, the OMPT says that such a monopolist upstream could only benefit from competition downstream, as this would maximise sales of its monopoly product. A monopolist therefore never has an incentive to reduce competition downstream.

27 Specific investments include: physical asset specificity, such as investing in a machine that produces a product required by only one buyer; site specificity, such as developing a manufacturing facility at a site near to the only buyer of the product in an area, which facility cannot easily be moved; human asset specificity, where a firm invests in staff to accumulate specific skills; and dedicated assets, which are invested in to serve the needs of very few buyers (Church \& Ware, 2000: 69).

28 Ultimately, this relationship broke down and GM was "held up". GM acquired the supplier, Fisher Body, partly so that Ford could locate Fisher Body 
factories closer to Ford factories, otherwise it would have entailed a further specific investment in Ford.

29 Motta points out, too, that vertical restraints may result in over-provision of services, as customers who do not want the additional services have to pay for them anyway; the welfare impact of increased service provision arising from vertical restraints is therefore ambiguous.

30 This ultimately failed as a defence in this case and the conduct was found to be anti-competitive. The behaviour nonetheless illustrates the point made here.

31 This discussion is generally based on one on the same topic in Gual et al (2005). A useful description of the efficiency-enhancing effects of price discrimination can be found in Bishop and Walker (2002: para. 6.26).

32 This is known as Ramsey pricing.

33 See Competition Appeal Court decision case number 49CACApr05, p. 26.

\section{References}

1 AREEDA, P. \& HOVENKAMP, H. (1996) Antitrust Law - Volume IIIA: An Analysis of Antitrust Principles and their Application, Little, Brown: Boston.

2 BISHOP, S. \& WALKER, M. (2002) The Economics of EC Competition: Concepts, Application and Measurement, Sweet \& Maxwell: London.

3 CHURCH, J. \& WARE, R. (2000) Industrial Organisation: A Strategic Approach, McGraw-Hill: New York.
4 EDWARDS, C. (1959) The Price Discrimination Law, The Brookings Institution: Washington, D.C.

5 EUROPEAN COMMISSION, DG COMPETITION (2005) "DG Competition discussion paper on the applicability of Article 82 of the Treaty to exclusionary abuses", available at: http://ec.europa.eu/comm/competition/antitrust/ art82/discpaper2005.pdf, accessed on 1 November 2007.

6 GELLHORN, E.; KOVACIC, W.E. \& CALKINS, S. (2004) Antirust law and economics in a nutshell, ( $5^{\text {th }}$ ed.) Thomson West, St. Paul, MN.

7 GUAL, G.; HELLWIG, M.; PERROT, A.; POLO, M.; REY, P.; SCHMIDT, K. \& STENBACKA, R. (the EAGCP) (2005) "An economic approach to article 82", available at: http://ec.europa.eu/comm/ competition/publications/studies/eagcp_July_21_ 05.pdf, accessed on 1 November 2007.

8 HILDEBRAND, D. (2005) Economic Analysis of Vertical Agreements: A Self-Assessment, Kluwer Law International: The Hague.

9 KWOKA, J. \& WHITE, L. (2004) The Antitrust Revolution: Economics, Competition and Policy, Oxford University Press: New York.

10 MOTTA, M. (2004) Competition Policy: Theory and Practice, Cambridge University Press: New York.

11 SALOP, S, \& RIORDAN, M. (1995) "Evaluating vertical mergers: A post-Chicago approach", Antitrust Law Journal, 63: 513 - 568.

12 VICKERS, J. (2004) "Speech to the $31^{\text {st }}$ conference of the European Association for Research in Industrial Economics, Berlin", available at: http://www.oft.gov.uk/news/ speeches/2004/0304, accessed on 1 November 2007. 